\title{
Drinking, Tap and Canal Water Quality Analysis for Human Consumption: A Case Study of Nawabshah City, Pakistan
}

\author{
Faheem Akhtar', Mansoor Ahmed ${ }^{2}$, Muhammad Naeem Akhtar \\ RECEIVED ON 02.09.2019, ACCEPTED ON 03.03.2020
}

\begin{abstract}
The quality of water is of the utmost importance and vital concern for the human beings since it has a direct link with the human health and welfare. If the drinking water or tap water gets contaminated, it can result in severe health problems. For example, if the drinking water contains over the limit amount of fluoride then it can lead to bone deterioration and other bone related problems. The purpose of the present study is to carry out quality analysis of drinking and tap water in Nawabshah City. The analyzed parameters are pH, TDS, Total Alkalinity, Total Hardness, Calcium Hardness and Electrical Conductivity. World Health Organization (WHO) standards are followed in the present study. Total 18 drinking water and tap water samples were collected from 6 different locations in Nawabshah City. The parameters that appeared to be within the limits are $\mathbf{P H}$ and total alkalinity whereas TDS, total hardness, calcium hardness and electrical conductivity crossed WHO standard limits at some locations.
\end{abstract}

Keywords: Water Quality Analysis, Physiochemical Analysis.

\section{INTRODUCTION}

$\mathrm{O}$ ne of the core factors for a healthy life is the safe drinking and tap water [1]. Underground and tap water are our two main water sources. Underground freshwater only comprises of $3 \%$ which is used approximately by 1.5 billion people for drinking [2]. According to one of the estimates $17 \%$ of the world population is drinking and consuming the water that is unsafe for the health, only $32 \%$ consume from safe water sources and the remaining $51 \%$ from pipe supply systems [3]. In Pakistan, unsafe drinking water is responsible for $40 \%$ of all deaths, $30 \%$ of all diseases and deaths of infants [4]. So many of the water borne diseases are directly linked with polluted water consumption like malaria, Diarrhea, intestinal worms, anemia etc. Industrial waste, agrochemical disposal and discharge of untreated effluents have been the leading causes of the contamination in groundwater [5]. Unfortunately, Pakistan lacks the surveillance and monitoring programs to verify the quality of drinking water and the situation gets worse when we consider the pathetic institutional and government arrangements. The purpose of the present study is to analyze different quality parameters of drinking as well as tap water in Nawabshah city, compare the obtained results with WHO standards and recommend the necessary measures to be considered.

\section{MATERIALS AND METHODS}

\subsection{Study Area and Sampling Locations}

Nawabshah is old name of Shaheed Benazirabad

${ }^{1}$ Department of Chemical Engineering, Quaid-e-Awam University of Engineering, Science and Technology, Nawabshah, Sindh, Pakistan. Email: faheemakhtar86@quest.edu.pk (Corresponding Author)

${ }^{2}$ Department of Chemical Engineering, Mehran University of Engineering and Technology, Jamshoro, Sindh, Pakistan. Email: ahmedmansoor419@gmail.com

${ }^{3}$ Department of Safety Science Engineering, Beijing Institute of Technology, Haidian District Main Campus, Beijing, China. Email: muhammadnaeemakhtar87@gmail.com

This is an open access article published by Mehran University of Engineering and Technology, Jamshoro under CC BY 4.0 International License. 
District of Sindh Province of Pakistan. It is the headquarter of the Shaheed Benazirabad District with a population of $1,135,131$. It is located at 26.25 latitude and 68.41 longitude with an elevation of 34 meters above sea level. Population wise, it is the $6^{\text {th }}$ biggest city in Sindh Province and therefore roughly the geographic center of it. In this city, $80 \%$ of the drinking water comes from surface source. The sample locations are listed in Table 1.

\subsection{Water Sample Collection}

Total of eighteen drinking water and tap water samples were collected specifically from both surface and ground water sources (Table 2). The samples were collected in sterilized PET bottles (Fig. 1) and kept at low temperature to preserve them from bio contamination. Tap water is the unfiltered water supplied to the tap and used for domestic purposes like washing and cooking. Whereas drinking water is the filtered water used at homes for drinking. Four samples were collected from each source from Quest Hostel, Bhangwar Colony, Sanghar Road and New Naka. Two samples were collected from Canal water source including Rohri canal and Gajra Wah. Sampling locations were selected from the main population zone and samples were taken in sterilized polythene $(1.5 \mathrm{~L})$ bottles, labeled with location names, point of source, type of water sample, date and time (Fig.1) and kept at room temperature. In the Quaid Awam University of Engineering, Science and Technology (QUEST) hostel, two of the male student dormitories were selected, named as Block $\mathrm{A}$ and Block H. Two samples of tap and drinking water were collected from each dormitory block. Two local houses were selected in Bhangwar colony from where two samples of tap and drinking water were collected from each house. From Sanghar Road and New Naka, two houses and two public hotels were selected for each location. From each selected house and public hotel, both tap and drinking water samples were collected.

\subsection{Parameters Tested}

Present study comprises of the seven water quality parameters that were analyzed from the collected samples. All the testing of the parameters was accomplished at the Laboratories of Energy and Environment Engineering Department, QUEST Nawabshah. Table 3 enlists the equipment that was used for analysis.

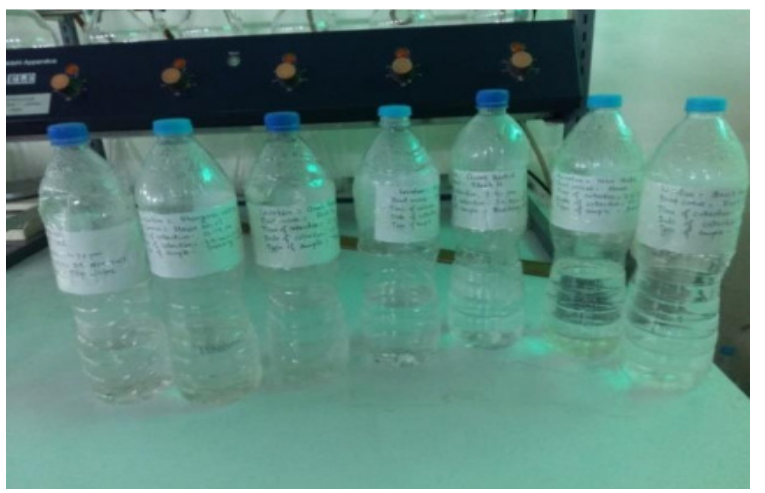

Fig. 1: Different Samples of Drinking and Tap Water

\begin{tabular}{|c|c|}
\hline \multicolumn{2}{|c|}{ Table 1: Sampling Location Names } \\
\hline Location Number & Location Name \\
\hline 1 & Gajra Wah \\
\hline 2 & Bhangwar Colony \\
\hline 3 & Sangha Road \\
\hline 4 & New Naka \\
\hline 5 & Rohri Canal \\
\hline 6 & QUEST Hostel \\
\hline
\end{tabular}

Table 2: Water Type from Sampling Locations

\begin{tabular}{|c|c|c|}
\hline $\begin{array}{c}\text { Sample } \\
\text { Number }\end{array}$ & Type Of Water & Location \\
\hline 1 & Tap Water & QUEST Hostel \\
\hline 2 & Drinking Water & QUEST Hostel \\
\hline 3 & Tap Water & QUEST Hostel \\
\hline 4 & Drinking Water & QUEST Hostel \\
\hline 5 & Canal Water & Gajra Wah \\
\hline 6 & Canal Water & Rohri Canal \\
\hline 7 & Tap Water & New Naka \\
\hline 8 & Drinking Water & New Naka \\
\hline 9 & Tap Water & New Naka \\
\hline 10 & Drinking Water & New Naka \\
\hline 11 & Tap Water & Bhangwar Colony \\
\hline 12 & Drinking Water & Bhangwar Colony \\
\hline 13 & Tap Water & Bhangwar Colony \\
\hline 14 & Drinking Water & Bhangwar Colony \\
\hline 15 & Tap Water & Sanghar Road \\
\hline 16 & Drinking Water & Sanghar Road \\
\hline 17 & Tap Water & Sanghar Road \\
\hline 18 & Drinking Water & Sanghar Road \\
\hline
\end{tabular}

\begin{tabular}{|c|c|}
\hline \multicolumn{2}{|c|}{ Table 3: List of Equipment Used } \\
\hline Apparatus Name & Model Number \\
\hline pH Meter & Model 215 \\
\hline TDS & Model 651 \\
\hline Total Alkalinity & - \\
\hline Total Hardness & - \\
\hline Calcium Hardness & - \\
\hline Magnesium Hardness & - \\
\hline Electrical Conductivity & GMH 3430 \\
\hline
\end{tabular}




\section{RESULTS AND DISCUSSION}

Table 4 shows the WHO standards for drinking water. Benchmarks of the present study results are made against these standards.

\begin{tabular}{|c|c|}
\hline \multicolumn{2}{|c|}{ Table 4: WHO Standards for Drinking Water } \\
\hline Parameters & $\begin{array}{c}\text { Permissible Limits by } \\
\text { WHO }\end{array}$ \\
\hline Temperature & $30^{\circ} \mathrm{C}$ \\
\hline Odour & Unobjectionable/Odorless \\
\hline $\mathrm{pH}$ & $6.5-8.5$ \\
\hline Hardness & $500 \mathrm{mg} / \mathrm{l}$ \\
\hline Total Dissolved Solids & $15000 \mathrm{mg} / 1$ \\
\hline Turbidity & $5 \mathrm{NUT}$ \\
\hline Conductivity & $120 \mathrm{YS} / \mathrm{cm}^{3}$ \\
\hline Chlorde Ion & $250 \mathrm{mg} / 1$ \\
\hline Alkalinity & $100 \mathrm{mg} / 1$ \\
\hline Color & $15 \mathrm{TCU}$ \\
\hline Appearance & $\mathrm{Clear}$ \\
\hline Bacteriological & - \\
\hline Coliform & Nil/100 ml \\
\hline E.Coli & Nil/100 m \\
\hline
\end{tabular}

\section{$3.1 \mathrm{pH}$}

$\mathrm{pH}$ basically is the extent of the hydrogen ion concentration in a solution. It measures the acidity or basicity of an aqueous solution. The values of $\mathrm{pH}$ indicate whether a solution is acid, base or neutral. Total range of values is $0-14$ where 7 specifies neutral. Below 7 is acid whereas above 7 postulates basicity [6]. WHO recommends $\mathrm{pH}$ value of drinking water to within the range of 6.5-8.5. Fig. 2 reveals the obtained $\mathrm{pH}$ results of 18 drinking and tap water samples collected from 6 different locations. The obtained values of all the locations are well within the limits of WHO standards. The highest $\mathrm{pH}$ value appeared in the sample No. 5 which is the canal water collected from Gajra wah as shown in Table 2. This may have been caused by the presence of agrochemicals such as plant nutrients and fertilizers in the locality [7, 14]. Buffering capacity as well as catchment of location's geological structure also have an impact over $\mathrm{pH}$ values of the water.

\subsection{Total Dissolved Solids}

Total Dissolved Solids (TDS) measures the presence of organic and inorganic substances dissolved in liquid. It can comprise of salts, heavy metals and some traces of organic compounds dissolved in water [8].
The standard value proposed by WHO is $1000 \mathrm{mg} / \mathrm{L}$. Water that has high amounts of TDS than WHO standard can have lethal and adverse effects on human health [9]. Measured values of the locations are shown in Fig. 3. All the values are well under the WHO standard limits except locations 9[T], 11[T] and 12[D]. $9[\mathrm{~T}]$ is the tap water collected from New Naka, 11[T] shows the tap water from Bhangwar Colony whereas $12[\mathrm{D}]$ is the drinking water sample also from Bhangwar Colony. Results show that the 2 samples out of 4 collected from Bhangwar colony exceed the desired TDS limits. Similarly one other drinking water sample from New Naka had not only exceeded limit but also the highest of all the samples. The most possible reason for such high TDS in the region may be the uncontrolled wastewater outflows from both domestic and industrial domains. Such domains consequently pollute the groundwater [10].

\subsection{Total Alkalinity}

Total alkalinity is the total concentration of bases and TDS in water expressed as parts per million (ppm) or milligrams per liter $(\mathrm{mg} / \mathrm{L})$ of Calcium Carbonate (CaCO3). The WHO standard limit in water is 500 $\mathrm{mg} / \mathrm{L}$. Low alkalinity can decrease the $\mathrm{pH}$ of water by increasing its sensitivity whereas High alkalinity may increase the $\mathrm{pH}$. It can also result in scale formation $[11,15]$. The results of Total Alkalinity are shown in Fig. 4. All the values obtained from all 18 samples are below the WHO standard limit which shows that the drinking and tap water in all the 6 locations have within limit concentration of bases and TDS.

\subsection{Total Hardness}

Total hardness measures the mineral content in water sample that cannot be reversed by boiling. It is sum of Calcium and Magnesium hardness in drinking water. The maximum limit set by WHO for total hardness is $500 \mathrm{mg} / \mathrm{L}$. Water with higher values of total hardness than WHO limit may have adverse health impacts on humans if consumed [12]. Fig. 5 shows the total hardness of 18 samples collected. All other samples were within the limits except 3;9[T], 11[T] and 12[D]. The highest value was observed in $9[\mathrm{~T}]$ which refers to the tap water sample collected from New Naka. Other sample that requires attention is the sample 
12[D] which is the drinking water sample collected from local house in Bhangwar Colony. This house has been consuming drinking water with high amounts of mineral contents which may result in health issues for that house residents.

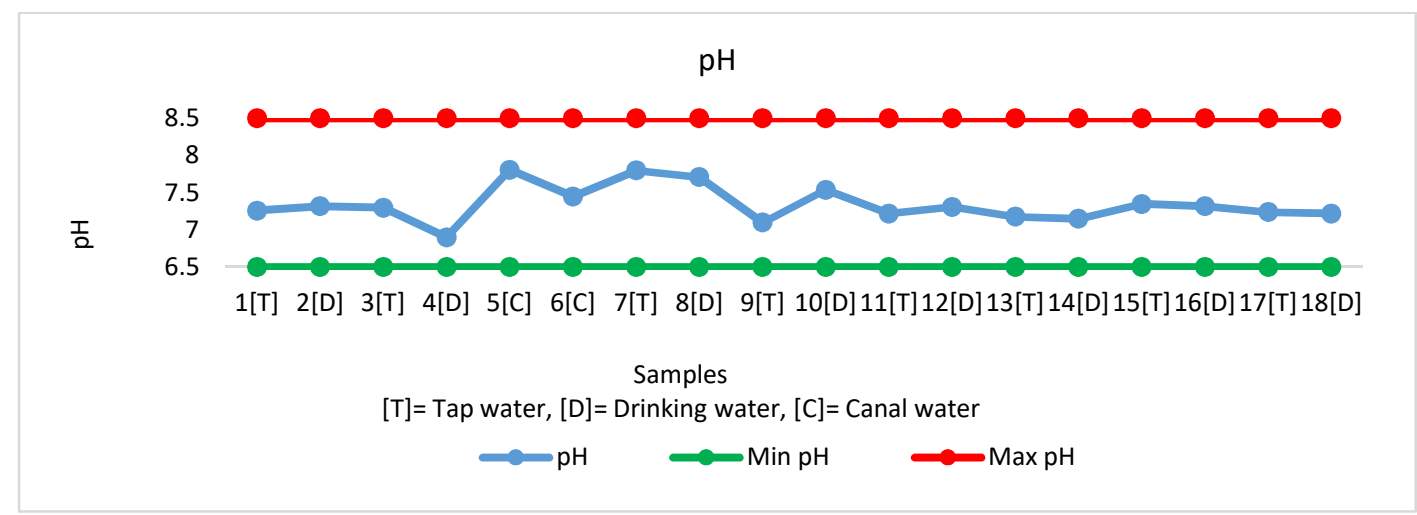

Fig. 2: pH Results of 18 Samples taken from 6 locations in Nawabshah City

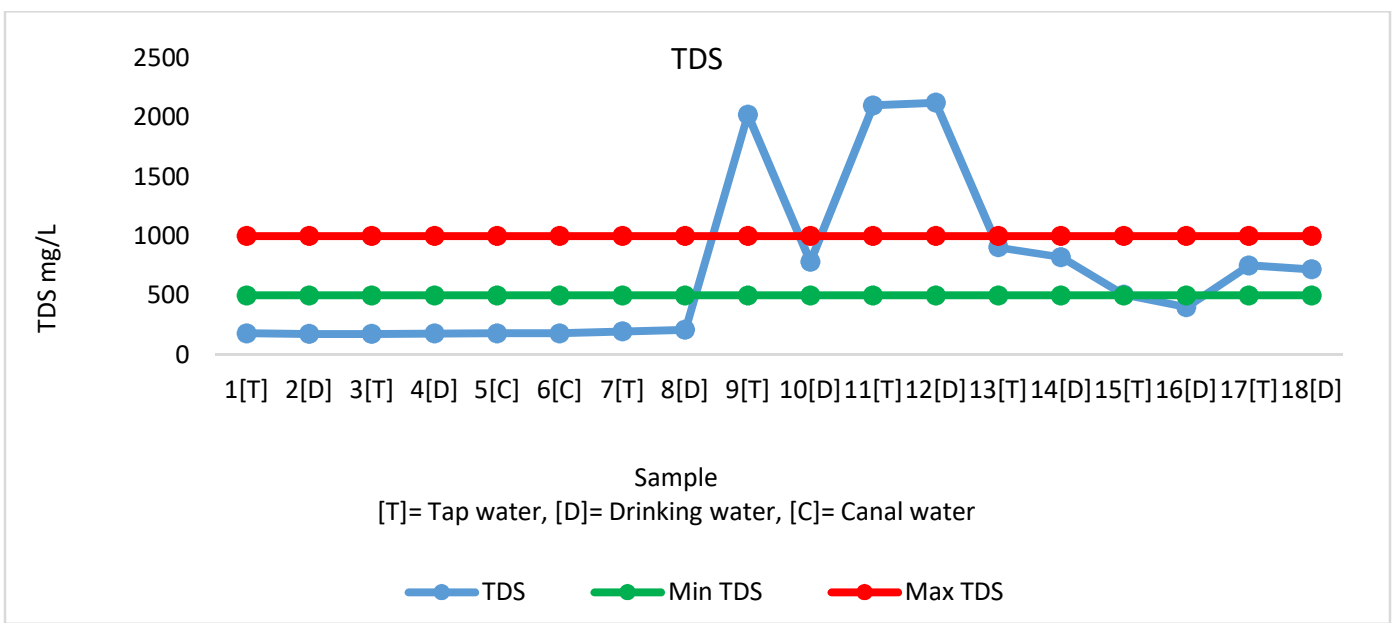

Fig. 3: TDS results of 18 samples taken from 6 locations in Nawabshah City

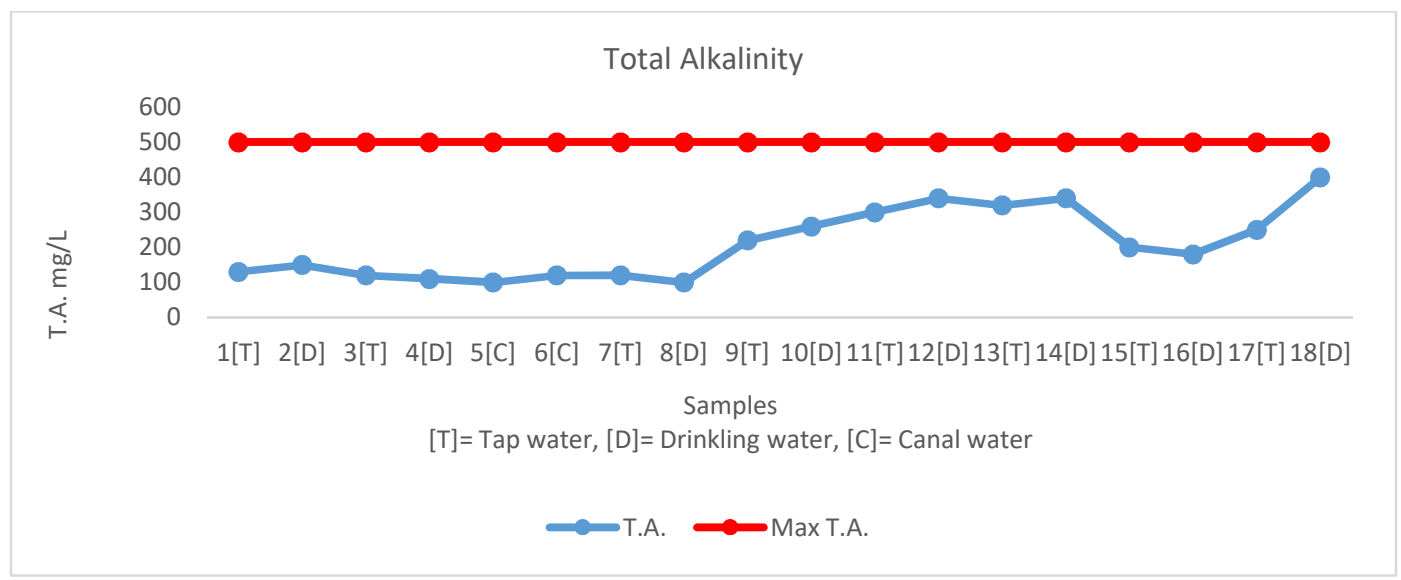

Fig. 4: Total Alkalinity results of 18 samples taken from 6 locations in Nawabshah City 


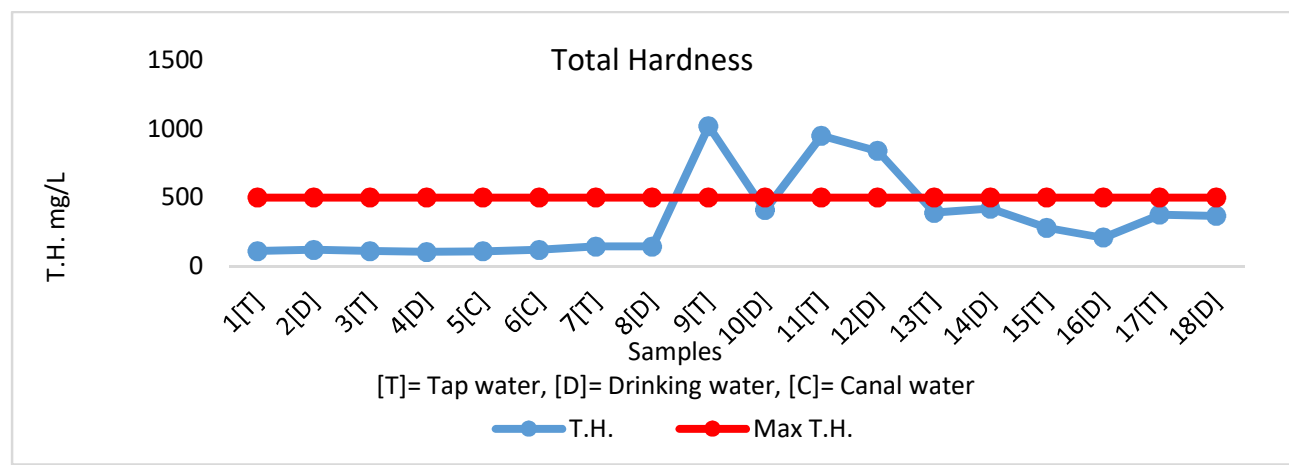

Fig. 5: Total Hardness results of 18 samples taken from 6 locations in Nawabshah City

\subsection{Calcium Hardness}

Calcium hardness refers to Calcium imbalance in water. It is the sum of all the Calcium dissolved in water. WHO standard limit for Calcium hardness is $200 \mathrm{mg} / \mathrm{L}$. Fig. 6 shows the results of obtained Calcium hardness values. Three locations 9[T], 11[T] and $12[\mathrm{D}]$ were found to have higher than standard limits of calcium hardness whereas three locations; $10[\mathrm{D}], 13[\mathrm{~T}]$ and $14[\mathrm{D}]$ appeared on the borderline of the limit. All the remaining samples were found to be below the standard limit.

\subsection{Magnesium Hardness}

Finding Magnesium hardness is an easy task after finding values of total hardness and Calcium hardness. If we have two values we can find the third value. We have calculated the value of Magnesium hardness by following method.

Total Hardness $(\mathrm{H})=$ Calcium $\mathrm{H}+$ Magnesium $\mathrm{H}$

So, Magnesium hardness will become:

Magnesium Hardness = Total Hardness - Calcium Hardness.
Fig. 7 shows the acquired results of the samples. The results are a bit shocking as compared to values of other parameter results because this test showed a total of 8 locations with higher than permissible amounts of Magnesium hardness. Of all the parameters tested in the present study, this test has the highest number of locations with impermissible values. Location with the highest impermissible value was $11[\mathrm{~T}]$ which refers to Tap water sample collected from a selected house in Bhangwar Colony. Higher Magnesium hardness in water contributes to hard water. Continuous consumption of hard water may affect health severely like causing cardiovascular diseases, Cerebrovascular Mortality and even cancer [16].

\subsection{Electrical Conductivity}

The Electrical Conductivity (EC) was measured with digital conductivity meter. As shown in Fig. 8, five samples exceeded the limits, two samples appeared on the line of limit and the remaining 11 samples showed satisfactory results. The exceeding values of EC indicate the sum of cation (or anion), or in other terms, the total concentration of salts. Higher temperature also makes the water prone to having higher value of EC [13].

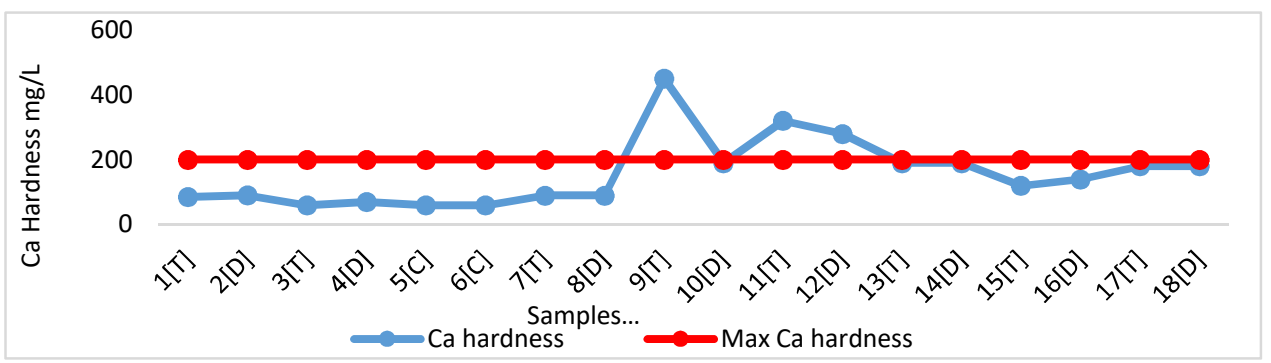

Fig. 6: Calcium Hardness Results of 18 Samples taken from 6 locations in Nawabshah City 


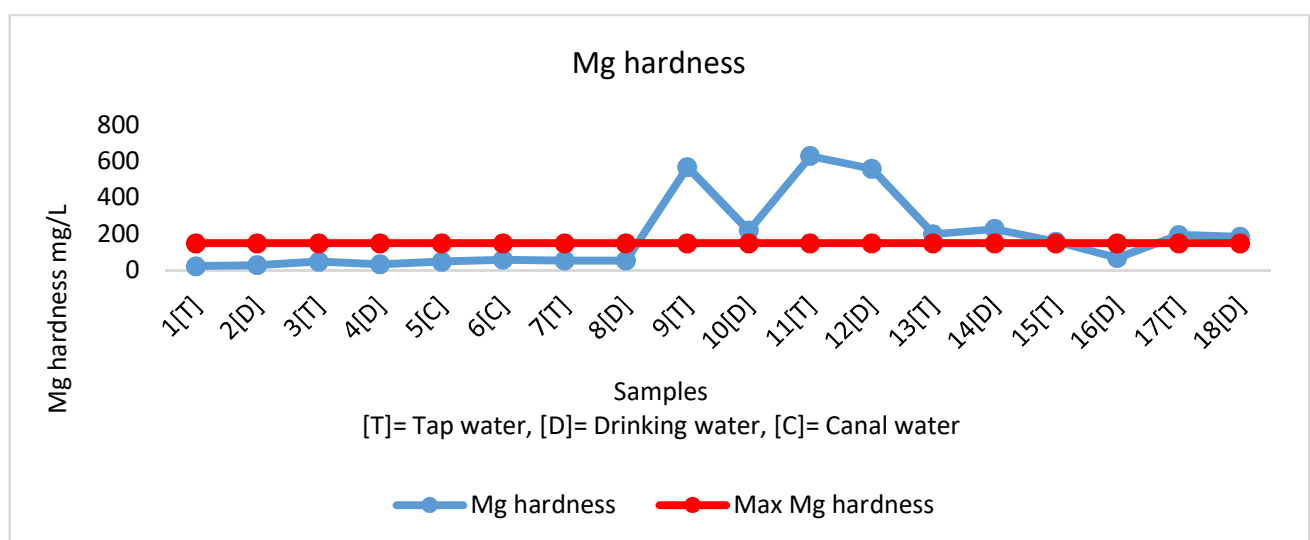

Fig. 7: Magnesium Hardness results of 18 Samples taken from 6 locations in Nawabshah City

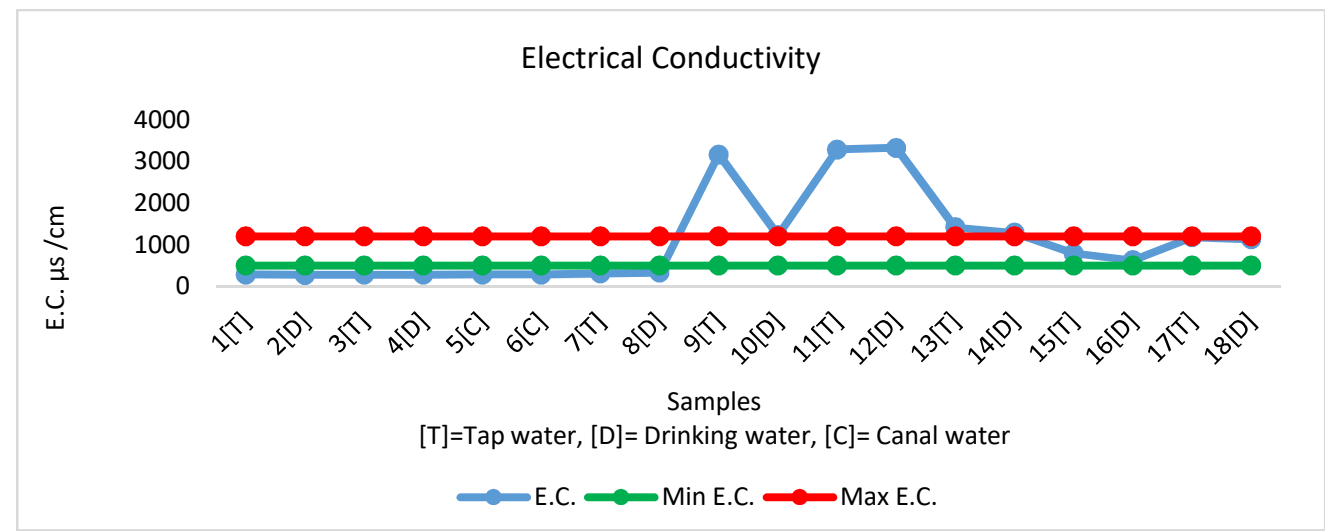

Fig. 8: Electrical Conductivity results of 18 samples taken from 6 locations in Nawabshah City

\section{CONCLUSIONS AND RECOMMENDATIONS}

It was concluded that overall quality of drinking and tap water was quite satisfactory as the values of most of the samples were within the limits. The only samples that showed higher values than permissible limits in almost all the tests were samples $9[\mathrm{~T}], 11[\mathrm{~T}]$ and $12[\mathrm{D}]$ respectively. Based on the results of this study, it is recommended that sample number 9[T], $11[\mathrm{~T}]$ and $12[\mathrm{D}]$, which refer to Tap water sample of New Naka; Tap water sample of Bhangwar Colony \& Drinking water sample from Bhangwar Colony, must be examined thoroughly and possible remedial measures should be taken such as installation of Sewage Treatment Plants (STPs), segregation of Agro-Industrial waste at source and using efficient water filtration units to filter drinking water at homes.

\section{ACKNOWLEDGEMENT}

Authors are thankful to the faculty of Energy and Environment Engineering Department for their assistance and support.

\section{REFERENCES}

1. Buamah R., Oduro C. A., Sadik M. H., "Fluoride removal from drinking water using regenerated aluminum oxide coated media.", Journal of Environmental Chemical Engineering, Vol. 4, No. 1, 250-258, 2016.

2. Suthar J. D., Rajper I., Depar N., Suthar V., "Ground-Water Quality in Islamkot and Mithi Talukas of District Tharparkar, Sindh, Pakistan," Mehran University Research Journal of Engineering and Technology, Vol. 38, No. 1, 143150, 2019.

3. Bhatti Z., Qureshi K., Bhatti I., Unar I. N., Khuhawar M. Y., "Determination of Arsenic and 
Health Risk Assessment in the Ground Water of Sindh, Pakistan", Mehran University Research Journal of Engineering and Technology, Vol. 36, No. 4, 143-150, 2017.

4. Khan K., Lu Y., Saeed M. A., Bilal H., Sher H., Khan H., Li Q., "Prevalent fecal contamination in drinking water resources and potential health risks in Swat, Pakistan", Journal of Environmental Sciences, Vol. 72, pp. 1-12, 2018.

5. Siyal A. A., Lakhair I., Babar M. M., Siyal P., Solangi G. S., "Study of Soil, Water, and Cropping Pattern in Danastar Wah (Manchar Lake) Command Area Using Geospatial Tools.", Mehran University Research Journal of Engineering and Technology, Vol 37, No. 4, pp. 655-668, 2018.

6. Mintenig S.M., Löder M. G. J., Primpke S., Gerdts G., "Low numbers of microplastics detected in drinking water from ground water sources", Science of the Total Environment, Vol. 648, pp. 631-635, 2019.

7. Barmentlo S. H., Schrama M., Hunting E. R., Heutink R., van Bodegom P. M., de Snoo G. R., Vijver M. G., "Assessing combined impacts of agrochemicals: Aquatic macroinvertebrate population responses in outdoor mesocosms", Science of the Total Environment, Vol. 631, pp. 341-347, 2018.

8. Devesa R., Dietrich A. M., "Guidance for optimizing drinking water taste by adjusting mineralization as measured by total dissolved solids (TDS)", Desalination, Vol. 439, pp. $147-$ 154, 2018.

9. Sharma A., Kundu S. S., Tariq H., Kewalramani N., Yadav R. K., "Impact of total dissolved solids in drinking water on nutrient utilisation and growth performance of Murrah buffalo calves.", Livestock Science, Vol. 198, 17-23, 2017.
10. Abdurahman S. G., Zewdie M., "Fluoride ion and total dissolved solid distribution in Ethiopian Rift valley: The case of Hawassa city aquifer.", Journal of Hydrology: Regional Studies, Vol. 19, 240-249, 2018.

11. Zhang H., Zhou X., Wang L., Wang W., Xu J., "Concentrations and potential health risks of strontium in drinking water from Xi'an, Northwest China", Ecotoxicology and Environmental Safety, Vol. 164, 181-188, 2018.

12. Lanz B., Provins A., "The demand for tap water quality: Survey evidence on water hardness and aesthetic quality", Water Resources and Economics, Vol. 16, 52-63, 2016.

13. Zawrah M. F., Khattab R. M., Girgis L. G., El Daidamony H., Abdel Aziz R. E., "Stability and electrical conductivity of water-base $\mathrm{Al} 2 \mathrm{O} 3$ nanofluids for different applications", $H B R C$ Journal, Vol. 12, No. 3, 227-234, 2016.

14. Pansini M., Sannino F., Marocco A., Allia P., Tiberto P., Barrera G., Esposito S., "Novel process to prepare magnetic metal-ceramic nanocomposites from zeolite precursor and their use as adsorbent of agrochemicals from water", Journal of Environmental Chemical Engineering, Vol. 6, No. 1, pp. 527-538, 2018.

15. Kovač A., Marciuš D., Budin L., "Solar hydrogen production via alkaline water electrolysis.", International Journal of Hydrogen Energy, Vol. 44, No. 20, pp. 9841-9848, 2019.

16. Sengupta P., "Potential health impacts of hard water", International Journal of Preventive Medicine, Vol. 4, No. 8, 866, 2013. 